\title{
水先人の乗下船および乗船時の人身事故発生傾向
}

\author{
林 祐司*・藤澤 邦臣 ${ }^{* *}$ 村井康二*
}

\section{Occurrence Tendency of Marine Pilots' Personal Accidents on Board}

\author{
Yuji HAYASHI, Kuniomi FUJISAWA and Koji MURAI
}

\begin{abstract}
A few of marine pilots have gotten severe personal accidents on board and closed their businesses. Their pilot associations have been struggling to keep their safety on board. However, their situations are not improved dramatically nowadays.

In this paper, we investigate into the marine pilots' personal accidents on board for 20 years from 1989 to 2008 . From the results of the investigations, we propose methods for keeping marine pilot safety on board. The results of the investigations show that their dangerous behavior happens between a pilot ladder and a pilot boat transfer. For avoiding such kind of dangerous situations, we propose to develop a supporting device for receiving falling them.
\end{abstract}

Keyword : sea disaster , pilotage, marine pilots 'personal accidents, death \& missing, time series analysis for pilots' behavior

キ一ワード：海難、水先制度、水先人人身事故、死亡・行方不明、水先人行動時系列分析

\section{1. はじめに}

\section{1 研究背景および研究目的}

水先人は乗下船時に転落等の人身事故に遭遇し、死 亡および行方不明を始め、水先業務を休業若しくは廃 業しなければならない深刻な被害を受けることがある。 そのため、水先人の乗下船時の安全確保は水先業務に 関係する組織や人にとって重要な課題となっている。 しかし、そのような状況が連綿と続いているにも関わ らず、水先人乗下船時の舷外転落事故（以下、重大人 身事故という。）は後を絶たない。一方、水先人乗下船 および乗船時の重大人身事故は、海難審判法第二条 (海 難の定義）第二項に定めるところの「船舶の構造、設 備または運用に関連した人の死傷」に該当すると考え られるが、海難審判の対象となることは稀で、多くの 重大人身事故の詳細は、関係者以外では知るところで
はなかった。以上の背景を踏まえ、本論では水先人の 乗下船および乗船時の安全確保のための第一段階の対 応として、水先人乗下船時の人身事故の発生状況を調 査する。そして、その調查結果を基にして水先人の乗 下船および乗船時の安全確保のための提案を行うこと を研究目的とする。この提案は、当該安全確保の一助 となることのみならず、同時に社会に対する水先業務 の重要性を訴える端緒(1)になるとも考える。

\section{2 水先人の乗下船方法}

水先人が㮣導対象船舶の乗下船の際に使用する水先 人用乗下船装置のうち、国内外で最も使用頻度の高い 装置としてパイロットラダーがあるが、この規格と運 用については国際条約、国内法等により定められてい る。主な条約および法令としては、SOLAS 条約 5 章 23

\footnotetext{
* 正会員 神戸大学大学院海事科学研究科（恧658-0022 神戸市東灘区深江南町 5-1-1)

** 学生会員 神戸大学大学院海事科学研究科（可658-0022 神戸市東灘区哚江南町 5-1-1）
} 
規則「水先人用乗下船設備」IMO 決議 A889「水先人用 乗下船設備に関する勧告」、水先法第 43 条「乗下船時 の安全措置」、水先約款 (例えば東京湾水先人会水先約 款第 6 条 (4) および第 10 条の (2)、船舶設備規程第 146 条の 39 「水先人用はしご等」、船舶安全法施行規則第 64 条「水先人用はしご等の使用制限」、国土交通省の 通達「海上技術安全局長の通達」、「海上技術安全局船 員部船舶職員課長の通達」等がある。規格の詳細につ いては IS0799「パイロットラダー」JISF2615「パイ ロットラダー」およびJISF2622「アコモデーションラ ダー」で定められている(2)(3)(4)(5)(6)(7)(8)。

一方、船舶乗組員へのパイロットラダーの適正な運 用については、各船操舵室に掲げられている国際パイ ロット協会作成の Required Boarding Arrangements for Pilot と題するポスターにより周知されており、 継続的な啓蒙活動が行われている。それに加えて、国 内では日本水先人会連合会が、水先人のための安全研 修を毎年 7 月から 8 月にかけて横浜、名古屋および神 戸の 3 都市で実施しており、各水先人会も毎年 7 月に 「乗下船安全キャンペーン」および「安全講習会」を 行っている。

他方、水先人が乗下船の現場まで移動するための手 段として用いる水先艇について、五大水先区のように 鄉導隻数の多い水先区では、各々で複数の水先艇を保 有しているが、響導隻数の少ない水先区では水先艇を 保有していない水先区もあり、水先業務の都度、小型 の侓船またはタグボートを用いて乗下船作業を行って いるというのが現状である。

\section{2. 研究方法および研究対魚}

本論で用いる水先人人身事故（以下、人身事故とい う。）は、転倒による打撲から舷外転落死亡に至るまで 多岐に渡る。これらに関する事故報告書等の資料は、 35 水先区水先人会に依頼し、31 水先区から提供を受け たものと日本水先人会連合会からの提供を受けた資料 で、1989 年から 2008 年までの 20 年間分の合計 92 件 の事故報告書等により構成されている。これら 92 件の 事故報告書等は同期間中に発生したすべての人身事故 を網羅したものではないが、92 件という数值から推定 して、その多くの部分を占めていると考えられる。
人身事故の調查については、年別発生数、月別発生 数、明暗別発生数について行う。また、人身事故の時 系列発生傾向を調查するために、水先業務の一連の作 業を時系列行動別に分割し、各行動における人身事故 発生件数を求める。これにより水先業務に関係する一 連の行動のうち、どの行動が水先人にとって危険度が 高いかを分析する。また、収集した 92 件の事故報告書 については、92 件全体および重大人身事故等に分けて 調査対象とし、それぞれの発生数を調查する。

\section{3. 分析結果および考察}

\section{1 年別人身事故発生件数}

\section{1 .1 年別人身亭故全体について}

本論で取り扱った人身事故は 1989 年から 2008 年ま での 20 年間で 92 件であり、年平均人身事故発生件数 は 4.6 件である。1999 年の IMO 決議による乗下船設備 に関する勧告を契機に、当該 20 年を前半 10 年間 (1989 年加ら 1998 年) と後半 10 年間（1999 年加ら 2008 年） の 10 年単位で二等分すると、前半 10 年間では 55 件の 人身事故（年平均 5.5 件）が発生している。後半 10 年 間では 37 件の人身事故（年平均 3.7 件）が発生してい る。

年別人身事故全体：

前半 10 年間 (55 件) > 後半 10 年間 (37 件) となり、Fig. 1 に示すとおり、10 年単位でみると人身 事故の年別発生件数は莪減している。その要因として、 前述の 1999 年の IM0 決議による乗下船設備に関する勧 告および 2002 年の SOLAS 条約の制定や改定という2つ の国際条約の効果が考えられる。

(Num.)

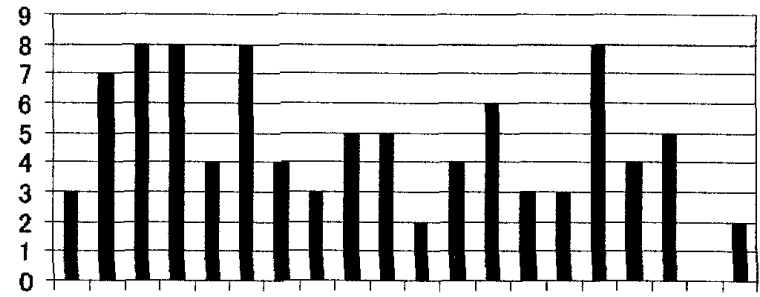

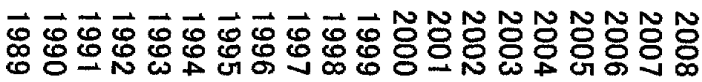

(Year)

Fig.1 Number of annual personal accidents 


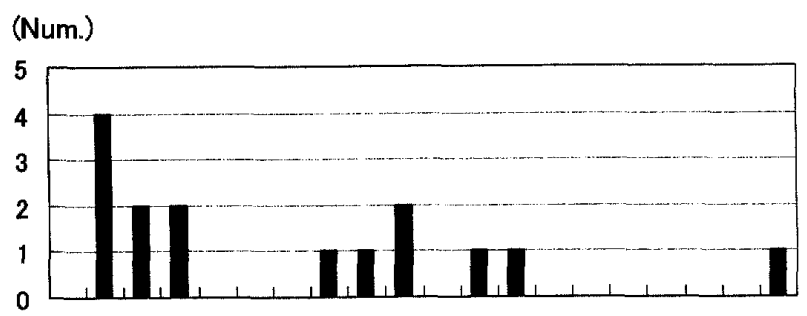

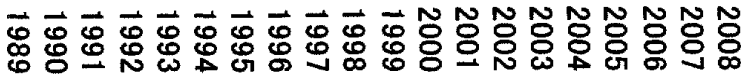

(Year)

Fig. 2 Number of personal accidents by pilot ladder handling

\section{1 .2 㖶用による年別人身事故について}

パイロットラダー等の設置（運用）不良に因って発 生した人身事故の年別人身事故発生件数を Fig. 2 に示 す。前項同様の 10 年単位でその発生件数をみると、 Fig. 2 に示すとおり、

運用年別人身事故 :

前半 10 年間 $(12$ 件) $>$ 後半 10 年間 $(3$ 件) と大きく減少している。

その要因としては、前述の 1999 年の IM0 決議および 2002 年の SOLAS 条約を受けて、日本国内においても 2004 年に日本水先人会連合会 (旧日本パイロット協会) は「水先人用乗下船設備およびその運用」を改訂して おり、それらの相乗効果によりパイロットラダ一等の 乗下船設備の運用面における人為的ミスによる人身事 故件数が減少している。

\subsection{3 荒天による年別人身事故について}

調査対象の 92 件の人身事故調査報告書等の中で、事 故の原因の一つとして卓越した風浪等の荒天に関する 記述のあるものは 32 件存在する。Fig. 3 には、それら の年別人身事故件数を表した。前項同様に前半 10 年間 と後半 10 年間とに分類して発生件数をみると、

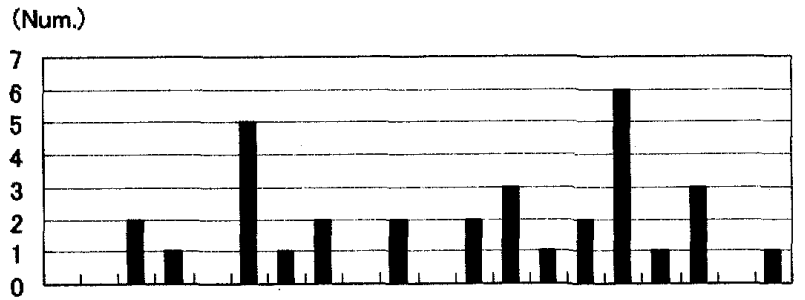

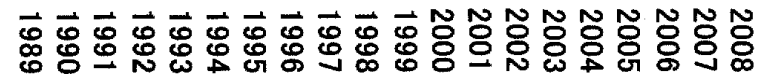

(Year)

Fig.3 Number of personal accidents by rough sea condition
荒天年別人身事故 :

前半 10 年間 $(13$ 件 $)<$ 後半 10 年間 $(19$ 件)

で、6 件微増している。各水先区では水先業務引き受 け基準を設定して、一定以上の荒天下での水先業務の 引き受けを制限しているが、関係者からの情報収集で は、制限限界を少し超える付近での引き受けが, 慣例に より行われている実態が存在する ${ }^{(9)}$ 。

\section{1 .4 年別重大人身事故について}

本論における重大人身事故とは、舷外転落事故を指 し、その結果として死亡、行方不明および生存を生じ た人身事故をいう。この重大人身事故の件数は 20 年閒 で 36 件発生した。前半 10 年間では 16 件の重大人身事 故 (年平均 1.6 件) が発生している。後半 10 年間では 20 件の重大人身事故(年平均 2.0 件) が発生しており、

10 年単位でみると重大人身事故の年别発生件数は

Fig. 4 に示すとおり 4 件の微增であった。

年別重大人身事故 :

前半 10 年間 $(16$ 件) $<$ 後半 10 年間 $(20$ 件)

\section{1 .5 年別人身事故のまとめ}

10 年単位で評価すると、年間人身事故件数は減少傾 向であり、同様に不適切なパイロットラダ一等の運用 が原因で発生した年別人身事故件数は激減している。 しかし一方では、荒天による年別人身事故件数と年別 重大人身事故件数は微增している。これらの分析結果 から推定できることは、パイロットラダーの設置等の 適正な実施により、人身事故は減少傾向にあり、人身 事故全体の発生数も同様の傾向を示しているが、荒天 等の理由により発生した人身事故は、全体の人身事故 の減少傾向とは逆の微増を示しており、舷外転落事故 である重大人身事故も同様の傾向を示している。

(Num.)

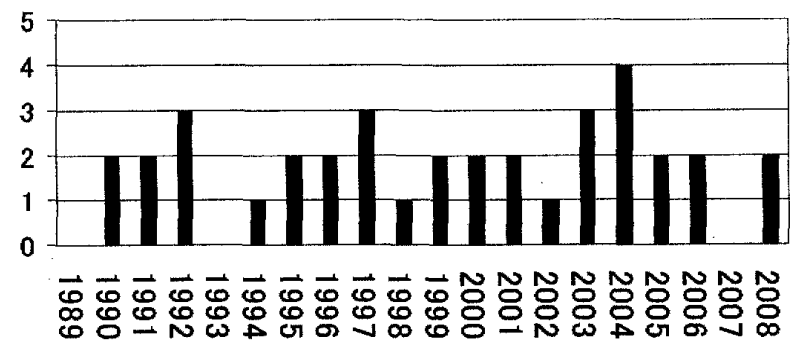

(Year)

Fig.4 Number of annual serious personal accidents 
(Num.)

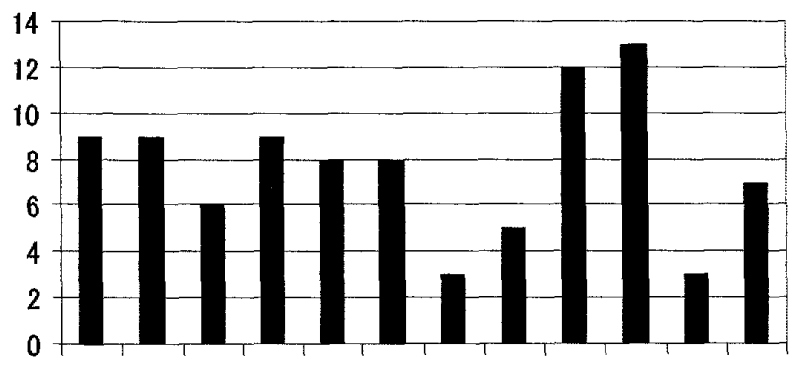

Jan. Feb.Mar. Apr. MayJun. Jul. Aug. Sep. Oct.Nov.Dec.

(Month)

Fig.5 Number of monthly personal accidents

水先業務引き受け基準の厳正な履行を行う上で、限界 条件付近での水先人個人の判断を支援するシステムの 構筮が必要である。これらの䛊判断を含め、ある一定 数の人的エラーが原因の年別重大人身事故が存在して おり、その年別重大人身事故の年平均值が 1.8 人であ り、換言すれば年間約 2 人の水先人が重大人身事故に 直面していることになる。

\section{2 月別人身事故発生件数}

\subsection{1 月別人身事故全体について}

Fig. 5 は、月別人身事故全体の発生件数を示してい る。これによれば、9 月、10月の発生件数がピークと なっている。この理由として、日本においては 9 月、 10 月に台風の来襲する機会が最も多くなり、台風およ びその前後の強風および高波によって人身事故が発生 しているためと考えられる。

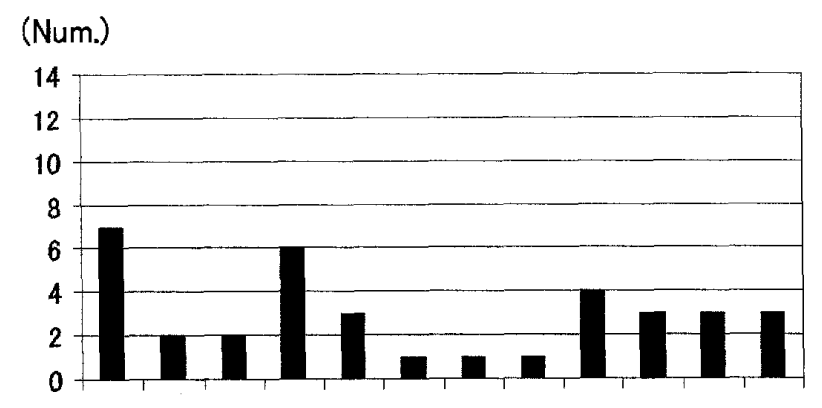

Jan.Feb.Mar.Apr. May Jun. Jul. Aug.Sep.Oct. Nov.Dec.

(Month)

Fig.6 Number of monthly serious personal accidents

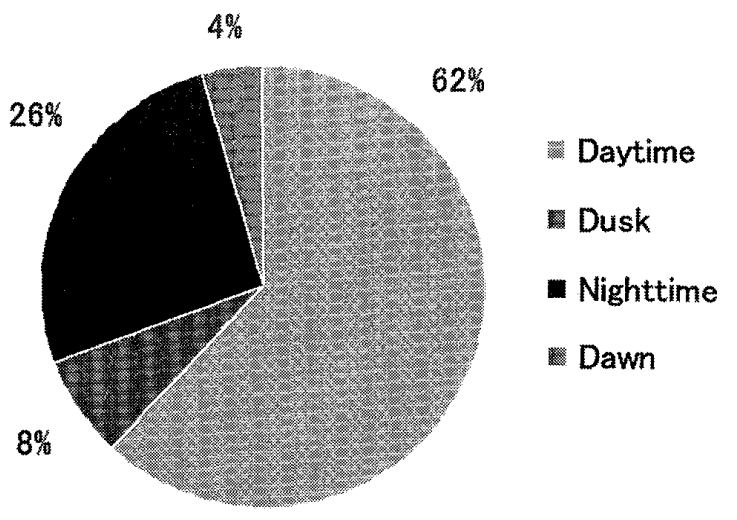

Fig. 7 Percentage of shading for personal accidents

\subsection{2 月別重大人身事故について}

Fig. 6 は、月別重大人身事故の件数を示している。 地方により季節は若干の差異があるが、1 年を春季 (3 月、 4 月、 5 月)、夏季 $(6$ 月、 7 月、 8 月)、秋季 $(9$ 月、 10 月、11月）および冬季（12月、 1 月、 2 月）と分割 してみると、春季 (11 件)、夏季 (3 件)、秋季 (10 件) および冬季（12 件）となる。1月に最大值をとること もあって相対的に気温と水温が低く、昼間より夜間が 長い季節に多く発生していると考えられる。

\section{3 明暗別人身事故睳生件数}

\subsection{1 明暗別人身事故全体について}

1 日を昼間 (日出から日没)、日没時薄明 (日没から日 没 1.5 時間後)、夜間 (日没 1.5 時間後から日出 1.5 時 間前）および日出時薄明（日出 1.5 時間前から日出） の 4 つの時間帯に分割し、明暗別人身事故の発生割合 を 92 件の人身事故について示した図が Fig.7である。 例えぱ、神戸港における各明暗時間帯の年平均時間は、 昼間 (12 時間 10 分 : 全体の $50.7 \%$ )、日没時薄明 (1.5 時間:全体の $6.3 \%$ )、夜間 (8 時間 50 分:全体の $36.8 \%$ ) および日出時薄明（1.5 時間：全体の $6.3 \%$ ） となる。 発生件数と割合は、昼間が 57 件（全体の $62 \%$ で 1 時 間あたりの值 4.7 ）、日没時薄明 7 件（全体の $8 \%$ で 1 時間あたりの值 4.7 ）、夜間 24 件（全体の $26 \%$ で 1 時 間あたりの值 2.7）および日出時薄明 4 件（全体の $4 \%$ で1 時間あたりの值 2.7）である。この結果から、昼 間と日没時薄明が 1 時間あたりの值が 4.7 となり、夜 間と日出時薄明の 1 時間あたりの值 2.7 を凌ぐ。また、 1 時間あたりの值から、水先人の明暗別時間帯に関す 


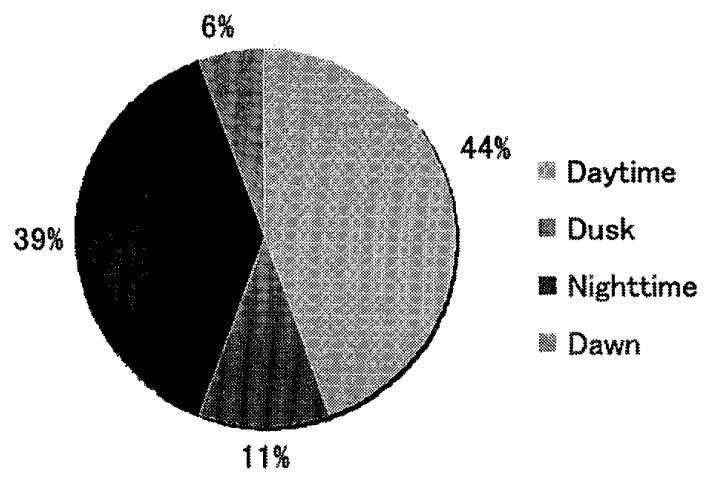

Fig.8 Percentage of shading for serious personal accidents

る明るさの労働環境の連続性は、昼間と日没時薄明 が連続性を持ち、夜間と日出時薄明が連続性を持つと 理解できる。

\section{3.2 明暗別重大人身事故について}

明暗別重大人身事故の割合を示した図が Fig. 8 であ る。発生件数は 36 件であり、各々の明暗別時間帯にお ける件数と割合は、昼間が 16 件（全体の 44\%で 1 時 間あたりの值 1.3 )、日没時薄明 4 件（全体の $11 \%$ で 1 時間あたりの值 2.7)、夜間 14 件（全体の $39 \%$ で 1 時 間あたりの值 1.6) および日出時薄明 2 件（全体の $6 \%$ で 1 時閒あたりの值 1.3) である。この結果から、日 出時薄明と昼間が 1 時間あたりの值が 1.3 となり、夜 間の 1 時間あたりの值 2.7 と日出時薄明の 1 時間女た りの值 1.6 を下回る。

\subsection{3 明暗別重大人身事故の死亡・行方不明に ついて}

明暗別重大人身事故のうち舷外転落後生存を除いた 重大人身事故、即ち、舷外転落後死亡または行方不明 になった人身事故の割合を示した図が Fig. 9 である。 発生件数は 9 件であり、各々の明暗別時間帯における 件数と割合は、昼閒が 1 件（全体の $11 \%$ で 1 時間あた りの值 0.1 )、日没時薄明 2 件（全体の $22 \%$ で 1 時間あ たりの值 1.3）、夜間 5 件（全体の $56 \%$ で 1 時間あたり の值 0.6)、および日出時薄明 1 件（全体の $11 \%$ で 1 時 間あたりの值 0.7）である。また、明るさが十分な昼 間と明るさが不十分な日没時薄明、夜間および日出時 薄明の件数と割合は、昼間が 1 件（全体の $11 \%$ で 1 時 間あたりの值 0.1 ）、日没時薄明、夜間および日出時薄 明の合計件数 8 件（全体の $89 \%$ で 1 時間あたりの值

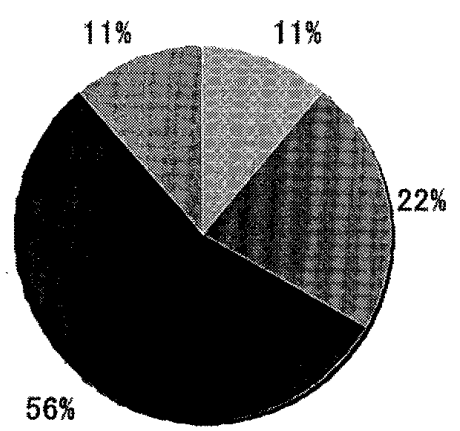

Daytime

Dusk

Nighttime

Dawn

Fig.9 Percentage of shading for personal accidents (death \& missing)

0.7)となる。要約すると明暗別時間帯においては夜間 における発生件数が 5 件と最も多く、夜間を含む明る さが不十分な明暗別時閒帯（日没時薄明、夜間および 日出時薄明）の合計件数が 8 件となり、発生件数の大 半を占めた。これらの結果より、重大人身事故のうち 死亡・行方不明が発生する明暗別時間帯流間を中核 に前後の日没時薄明および日出時薄明に集中して発生 していることが分かる。この原因として、不十分な明 るさの環境下で舷外転落が発生した場合、転落者を見 失い行方不明となる可能性が高く、発見できても長時 間かかり、溺死に繋がるものと考えられる。この対策 としては、舷外転落者の早期の救命が肝要で、そのた めには容易に発見しやすい色彩で防寒性に優れる日本 水先人会連合会が開発参画したパイロットコートの着 用の義務化や水先艇の強力な探照灯の充実と的確な運 用の強化、水先艇乗組員の増員による乗下船支援およ び救急救命担当の充実が挙げられる。

\section{4 時系列行動別人身事故発生件数}

\subsection{1 時系列行動別人身事故全体について}

最も作業行程数の多い水先業務 (陸上 $\rightarrow$ 水先艇 $\rightarrow$ 本船 $\rightarrow$ 水先艇 $\rightarrow$ 陸上）の作業を時系列に分割し、 各作業および作業間における人身事故発生件数につい て分析する。本論では水先業務を 19 の作業および作業 間行動（以下、総称して行動という。）に分割して、水 先人の時系列行動別人身事故発生件数の調査を行った。 その結果を Fig. 10 に示す。

全行程閒の人身事故発生傾向を考察するために、 


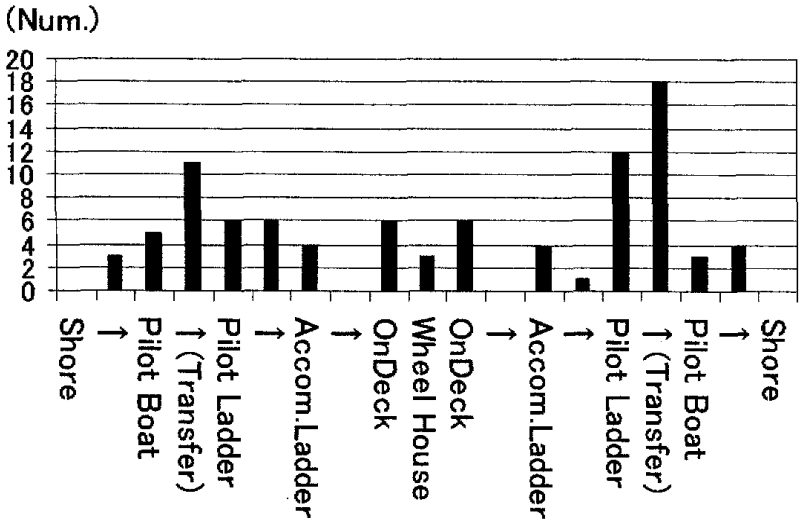

Fig.10 Number of personal accidents for each process

各々の行動時の人身事故発生件数に注目すると同時に、 全体の発生傾向を考察するために、19の行動に対し操 舵室 (船舶留導行動) を境界に乗船行程（陸上 $\rightarrow$ 水 先艇 $\rightarrow$ パイロットラダー $\rightarrow$ アコモデーションラダ 一 $\rightarrow$ 甲板上）と下船行程（甲板上 $\rightarrow$ アコモデーシ ヨンラダー $\rightarrow$ パイロットラダー $\rightarrow$ 水先艇 $\rightarrow$ 陸 上）とに大別する。

各行動のうち極大值をとるのは、茟船行程において は水先艇からパイロットラダーへの移乗時で、下船行 程ではパイロットラダーから水先艇への移乗時である。 また、下船行程のパイロットラダ一上の行動における 発生件数が多い。

時系列行動別人身事故全体の発生件数を見ると、

乗船行程 (41 件) <下船行程 (48 件)

で、下船行程における人身事故発生件数が多い。 水先艇とパイロットラダー閒の双方向からの移乗行 動における人身事故発生件数は、

乗船行程 $(11$ 件 $)<$ 下船行程 $(18$ 件 $)$

と、下船行程における人身事故発生件数が多い。 パイロットラダー上での行動における人身事故発生 件数は、

乗船行程 $(6$ 件 $)<$ 下船行程 $(12$ 件 $)$

となり、下船行程の值が大きく上回る。

これらの結果から、下船行程の各行動に、より注意 を要することが必要で、特に水先艇とパイロットラダ 一閒の双方向からの移乗には、より強力な安全対策が 肝要である。また、下足元の安全確認が困難である下 船行程におけるパイロットラダー上での安全確保も急

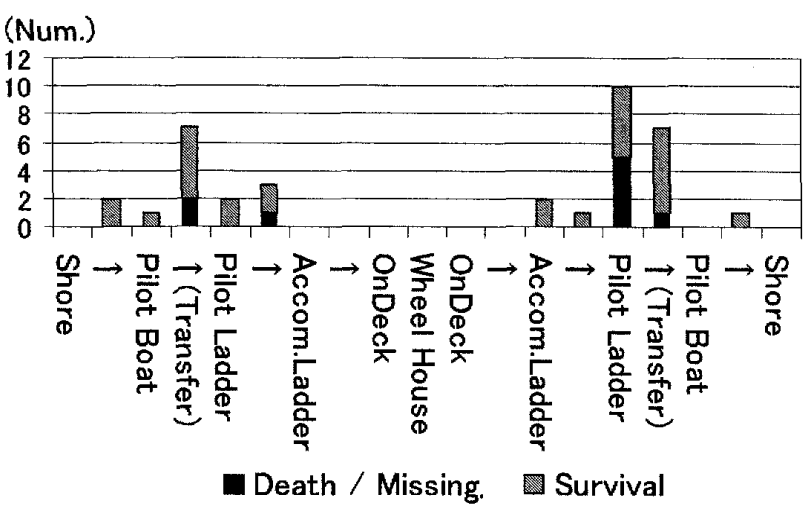

Fig.11 Number of serious personal accidents for each process

務である。

これらの危険な行動は、水先業務に携わる者であれ ば経験により既知 ${ }^{(9)}$ であるため、十分に注意をして いるが、それでも発生件数が高いということから、パ イロットラダーを使用した乗下船方法自体が危険度の 高いものであるということが分かる。パイロットラダ 一を使用して乗下船を行う限り、水先人の人身事故を 撲滅することは困難と考えられる。そのため、パイロ ットラダーを使用しない乗下船方法が必要とされ、そ の一例として一部船舶で行われているテンダーシェル ドアの利用およびへリコプターによる乗下船方法が挙 げられる。

\subsection{2 時系列行勳別重大人身事故について}

Fig. 11 は、時系列行動別人身事故のうち重大人身事 故発生件数を表したものである。重大人身事故の発生 件数は、

乗船行程 $(15$ 件 $)<$ 下船行程 $(21$ 件)

であり、そのうち水先艇とパイロットラダ一間の移乗 時では、

乗船行程 (7 件) $=$ 下船行程 (7 件)

であり、パイロットラダー上では、

乗船行程 $(2$ 件 $)<$ 下船行程（10 件) であった。

時系列行動別人身事故発生傾向と時系列行動別重大 人身事故発生傾向は、ほぼ同じ傾向を示した。但し、 パイロットラダー上での発生件数の差が拡大している。 いずれの行動も水先人の不安定な体勢が共通しており、 
水先艇やパイロットラダーに波浪などの強い衝撃が生 じた場合には、その体勢が崩れ易いということである。 パイロットラダーによる乗下船方法では、これらの不 安定な体勢の除去が、水先人の安全な乗下船を実現す る根本的な対策である。

一方、下船行程の重大人身事故の特徴としては、乗 船行程と異なり、パイロットラダー上での行動に多く 発生しているという点である。パイロットラダー上の 事故の原因については、原因の判明しているものでは 気象、海象が挙げられているが、半数以上は事故報告 書等からは原因を特定することができなかった。その ために下船行程のパイロットラダー上での重大人身事 故を未然に防ぐための対策は、重大事故が発生した場 合に被害を最小限に抑制するという観点で考えなけれ ばならない。そのためにパイロットラダー上の水先人 の安全を確保するための乗下船支援装置の開発と運用 が肝要である。パイロットラダ一本体についての改良 は、国際規格である ISO によって定められているため、 早急に実施することは困難である。そのために水先艇 側での対応を前提とした乗下船支援装置の開発が妥当 といえる。

\section{4. 提案}

これまでの水先人乗下船および乗船時の人身事故の 発生傾向の調查結果により、重大事故に焦点を絞って その防止対策案を転落防止と転落時の救急救命の観点 より提案を行う。

転落防止対策案は、1)水先業務引受け基準の遵守に より、限界をやや上回る気象海象状態での引き受けを 抑制する。2) 水先艇員を常に複数化し、水先人の乗下 船時には水先艇の操船担当者と乗下船支援担当者を分 離する。3) 同様の人身事故回避のために、発生した事 故の詳細および対策を当該水先人会会員のみならず全 国の水先人および関倸者に遅滞なく公表する。

一方、不幸にして水先人が転落した時の救急救命対 策案は、4)より視認性および防寒性に優れるパイロッ トコートの着用義務化を実現する。5)転落時の救命の ための安全乗下船支援装置の開発と円滑な運用を実現 する。

提案した 3 つの転落防止対策案および 2 つの救急救
命対策案の実現に向けて、日本水先人会連合会および 各水先人会の強いリーダーシップの履行を期待する。 但し、5)安全乗下船支援装置の開発については産学官 の連携によって早期に実現すべきであると考える。

\section{5. まとめ}

本論では、水先人乗下船時の人身事故の発生傾向を 調查し、それらを基にして水先人の乗下船および乗船 時の安全確保のための提案を行った。事故報告書に該 当する 20 年を前半 10 年間（1989 年から 1998 年）と 後半 10 年閒（1999 年から 2008 年）の 10 年単位で二 等分して分析を行った。

水先人乗下船時の人身事故の発生傾向は、

(1) 年別人身事故発生件数については、

- 全体年別人身事故 :

前半 10 年間 (55 件) $>$ 後半 10 年間 (37 件)

- 運用年別人身事故 :

前半 10 年間 $(12$ 件) $>$ 後半 10 年間 (3 件)

- 荒天年別人身事故 :

前半 10 年間 $(13$ 件) $<$ 後半 10 年間 $(19$ 件)

・年別重大人身事故 :

前半 10 年間 $(16$ 件) $<$ 後半 10 年間 $(20$ 件)

（2）月別事故発生件数については、

9 月、10 月が台風による発生件数が相対的に多い。

（3）明暗別重大人身事故(死亡・行方不明)については、 明るさが不十分な明暗別時間帯（日没時薄明、夜間 および日出時薄明）の合計発生件数が 8 件であり、発 生件数全体の大半を占める。

（4）時系列行動別人身事故発生件数については、

- 全体時系列行動別人身事故：

乗船時 (41 件) <下船時 (48 件)

- 時系列行動別重大人身事故 :

乗船行程 (15 件) < 下船行程 (21 件)

うち、パイロットラダー間の移乗時では、

乗船行程 $(7$ 件 $)=$ 下船行程 $(7$ 件 $)$

パイロットラダー上では、

乗船行程 $(2$ 件) $<$ 下船行程（10 件）

であった。

水先人の乗下船および乗船時の安全確保のための提 案は、転落防止対策案として、水先業務引受け基準の 
遵守、水先艇員の複数化および人身事故詳細の公表が 挙げられる。また、救急救命対策案は、パイロットコ 一ト着用の義務化および安全乗下船支援装置の開発と 運用を提案した。

今後の課題としては、安全乗下船支援装置の開発が 急務であると認識をしている。

\section{蜊辞}

本論調査のために資料提供にご協力いただきました 日本水先人会連合会および各水先区水先人会に対して、 深甚なる感謝の意を表します。

\section{券考文献}

（1）林祐司・村井康二：日本国内における水先人衝突 海難の発生傾向 一関門水先区の場合一, 航海学 会論文集，No. 119，pp153-160，2008.9

(2) IS0 : IS0799 - 2004(E) Ship and marine technology - Pilot ladders, 2004

（3）日本工業規格：パイロットラダーJIS F2615 Ship and marine technology - Pilot ladders, 2004

（4）日本工業規格:パイロットラダー用船側はしごJIS F2622 Pilot accommodation ladders, 2004

（5）（社）日本水先人会連合会 : 日本水先人会連合会 HP http://www.pilot.or.jp/, 2009.2

（6）国土交通省：国土交通省 HP http://www. mlit. go. jp/maritime/index. html, 2009. 2

（7）（社）日本水先人会連合会 : 水先人用乗下船設備及 びその運用，日本水先人会連合会（旧日本パイロ ット協会), 2004

(8) 船舶安全学研究会: 船舶安全学概論, 成山堂書店, 2000

（9）藪内稔：一隻入魂, 成山堂書店, 1999

\section{貫疑応答}

逸見 真 (海技大学校)：

安全乗下船支援装置の具体案はありますか。 林祐司 :

現時点で構想している当該装置は、水先艇に設置し
て、水先人の転落時に水先人を受け止める装置です。 具体的には、パイロットラダーが設置された本船乾舷 に沿って垂直方向の自由度を持つ半円状のネットを考 えています。開発のための共同研究を行う企業等を求 めています。 